\title{
"This Aggression Will Not Stand": Myth, War, and Ethics in The Big Lebowski
}

\section{Todd A. Comer}

\begin{abstract}
Now this story I'm about to unfold took place back in the early nineties - just about the time of our conflict with Sad'm and the Eye-rackies. I only mention it 'cause sometimes there's a man-I won't say a hee-ro, 'cause what's a hee-ro? - but sometimes there's a man. . . and I'm talkin' about the Dude here-sometimes there's a man who, wal, he's the man for his time'n place, he fits right in there-and that's the Dude, in Los Angeles. . . (Coen screenplay, 4; my emphasis)
\end{abstract}

In Joel and Ethan Coen's 1998 film The Big Lebowski, The Stranger's opening voiceover poses the following question: In a world controlled by "I's," by states intent upon realizing an extreme freedom through violence, how should the singular person respond? The "eye" is linked to what Donna Haraway describes as the "cyclopean self-satiated eye of the master subject" (192). As such it is the I/eye of the Cartesian subject for whom sight is always a violent affair. This juxtaposition of conflict and heroism in The Stranger's comments then frames the entire film. The Stranger implies that confronting the "I's" demands as a traditional "hero" then reproduces an exclusionary and violent subject. Indeed, it is fair to say that the traditional hero exemplifies subjectivity in the way that narratives coalesce around such archetypes. While The Stranger doesn't want to argue that "the Dude" (Jeff Lebowski) is a hero, he indicates that the Dude is "heroic" and somehow a response to the tyranny of the "I." Yet The Stranger readily admits that he is "stupef[ied]" by the Dude and his story (Coen screenplay, 3). On a narrative level, this undermines the "story" that The Stranger is preparing to relate. A hero-less, "stupefying" story is hardly a story at all. All of this is doubly strange when we consider that The Stranger is played by a famous western actor, Sam Elliott, whose narrative consequently ought even more rigorously to fulfill the requirements of traditional narrative structure. Who, we wonder, will provide coherence and closure to his narrative?

(C) Board of Regents, University of Wisconsin System, 2005 
Unlike such Coen productions as Miller's Crossing, Fargo, and O, Brother, Where Art Thou?, The Big Lebowski does not possess a coherent narrative. Rather, it could be described as an interrupted narrative insofar as it fails to bring cohesion to the differences that mark it. Examples are numerous. I will simply point to the intrusion of the pornographic and detective genres in what is framed as a Western film and, moreover, shot through with western stylistic motifs. Lebowski can then be understood as a traumatized filmic narrative that attests to the impossibility of absolute immanence, the notion that identity can exist apart from relation to others. Such narrative incoherence represents a relation - what I term the spacing of singularity - that interrupts the subject and, crucially, its violence. I read The Big Lebowski in order to think through the problem of narratival, or mythic violence, and how, ultimately, to interrupt myth in the exterior world of Bush, Hussein, and the Persian Gulf. I argue that mythic narratives-westerns in particular-operate as works of mourning, endlessly assimilating wartime trauma to immanent and violent supra-subjects, such as nations. Ultimately, my interest is in interrogating the ways in which myth is interrupted in postmodern film and how myth's unworking, through what I will call for the moment an (im)proper mourning, can be seen as an ethical - and yes, "heroic" response to those violent "Eye-rackies."

I will begin by elaborating on the issues of violence, war, and heroism as a way of mapping out the thematic terrain within the film, before extending my analysis. If the Dude is indeed a "hero," his heroism has something to do with "casualness," "his rumpled look and relaxed manner" as he is initially described (Coen screenplay, 3). The Stranger wraps up the film with a reiteration of this casualness, "It's good knowin' he's out there, the Dude, takin' her easy for all us sinners [read violent "Eye-rackies"]" (140). The best evidence for reading the Dude's casualness (i.e., pacifism) as a privileged response to violence comes in an early scene with Walter, a Vietnam vet. After Walter pulls a gun on a fellow bowler who steps over the foul line during a game, the Dude responds with one of his key phrases, "just take it easy." Walter counters with, "That's your answer to everything, Dude. And let me point out-pacifism is not-look at our current situation with that camel-fucker in Iraqpacifism is not something to hide behind." Here, we have in miniature the Persian Gulf War: A border has been crossed, rules have been violated, and violence results. Most important, the question of what constitutes an appropriate response to such violence has also been broached. However, what I want to highlight at this point is the Persian Gulf War context-acted out here in miniature - and Walter's policing of the border. 
This policing is the work of an immanent subject preserving a stable world and keeping difference at bay in the context of the nation.

As The Stranger continues his monologue, we watch a tumbleweed roll through the desert, through the city, and along the ocean shore before an abrupt, telling, cut to the Dude walking casually through a supermarket. At a cash register, a television transmits George Bush Sr.'s famous sound bite following Iraq's invasion of Kuwait, "This is a call for collective action ... This aggression will not stand."1 Bush's statement sets up the next scene's violence as yet another enactment of the Kuwaiti invasion: Pornographer Jackie Treehorn's thugs misidentify the Dude, Jeffrey Lebowski, as the "big" Lebowski, a wealthy conservative whose spouse, Bunny, has reneged on a loan. Before realizing their mistake, Treehorn's thugs break into the Dude's apartment, attack him, and urinate on his rug. In the later dream sequence, the rug becomes a flying carpet that again draws us toward the Persian Gulf War: the rug (much like Kuwait) is pissed on. In a curious fashion, the Dude uses the same rhetoric as Bush in responding to his loss. When confronting the big Lebowski with his soiled rug - a confrontation that was Walter's idea to begin with-he reproduces Bush's rhetoric, "This will not stand, man" (Coen, 18 ) in his defense. In a small way, he becomes Bush.

Left alone, the Dude, a self-proclaimed pacifist, would not have reacted to this attack. ${ }^{2}$ Ironically, he allows veteran Walter to badger him into action. Walter begins by repeatedly stressing that "this was a valued rug ... that tied the room" together (Coen, 9-12). Suddenly a rug that operates as a center of fashion is blown into a geopolitical issue. Walter's obsession with protecting the center continues: when Donny, the marginalized bowling buddy, interrupts with a question, Walter berates him for having "no frame of reference." Momentarily confused by Donny, Walter is at a loss for words and cannot explain the "point" of his meditation on the "valued rug." Invariably, he returns to his military experience and then to the current Bush rhetoric, "We're talking about unchecked aggression here." And, then a little later, "I'm talking about drawing a line in the sand, Dude. Across this line you do not..." Elsewhere Walter says, "there is no reason, no fucking reason, why ... [the "big" Lebowski's] wife should go out and owe money and they pee on your rug. Am I wrong?" By the end of the conversation, the Dude recapitulates Walter's argument with hardly any variation.

In short, violence is motivated by those who are far more articulate than the Dude. Let's look at a more extended example. The following conversation occurs some time after Maude Lebowski first knocks the Dude unconscious in order to retrieve her rug: 


\section{MAUDE}

... All right, Mr. Lebowski, let's get down to cases. My father [the "big" Lebowski] told me he's agreed to let you have the rug, but it was a gift from me to my late mother, and so was not his to give. Now. As for this ... "kidnapping"

DUDE

Huh?

\section{MAUDE}

Yes, I know about it. And I know that you acted as courier. And let me tell you something: the whole thing stinks to high heaven.

\section{DUDE}

Right, but let me explain something about that rug ...

MAUDE

Do you like sex, Mr. Lebowski?

\section{DUDE}

... Excuse me?

\section{MAUDE}

Sex. The physical act of love. Coitus. Do you like it?

\section{DUDE}

I was talking about my rug.

\section{MAUDE}

You're not interested in sex?

\section{DUDE}

... You mean coitus? (Coen screenplay, 60-61)

Maude, like Walter, confuses her listener and controls conversation. By contrast, the Dude does not originate language, but exists as a receptacle for others' conversation. In the above scene, the Dude repeats Maude's use of the word "coitus." Elsewhere we see the Dude reproducing phrases like "in the parlance of our time," "special lady," or, even, "johnson." Maude's foray into sex centers on her search for a man who would be willing to impregnate her and then leave both her and the future child alone. It is a predatory conversation in which the Dude is kept under tight discursive control. Much the same happens between Walter and Donny when the former castigates the latter for his lack of concentration and inability to achieve a frame of reference. Since clear, uncluttered narratives are essential for power to function, Walter finds Donny's inattention (and nonsensical interruptions) threatening. By contrast, the Dude could be said to be much too attentive to Walter in conversation. 
The film continually opposes aggression to a liberal order of protestpacifism -in which, as Ward Churchill describes it, "good feelings and purity of purpose" are expected to prevail over violence (30). In the case of the Dude's pacifism, the painful fact is that his presence does not hinder violence. Instead, the Dude is complicit with the violence that kills Donny. With Lyotard, we could say that this opposition, this "polemos" between Walter and the Dude, works to hide some "thing that has no relation to the mind," something that cannot be thought easily by the subject (44). The Dude is complicit in this violence because he represents no difference to the homogeneous world of Walter. Walter, in this case, needs to be understood as an exemplary "rational" subject. By rational, I mean to suggest that Walter's assimilation of the world is both self-interested and economic: everything that is different must be made sense of and be "fashioned" to stabilize the self. Herder once wrote, "What can be fashioned by man? Everything. Nature, human society, humanity" (qtd. in Nancy, Inoperative Community, 3). Reading Walter as a rational subject may appear a stretch until one recalls the way in which he pontificates, endlessly intent on demonstrating his knowledge ("I mean 'Nam was a foot soldier's war whereas, uh, this thing [the Persian Gulf War] should be a fucking cakewalk" [Coen, 125]). In such a solipsistic world, any effort to dissuade a character like Walter from action is an immediate failure, since rationality violently assimilates such disruptions. The Dude falls prey to this fashioning easily and, in view of his position in "opposition" to Walter, encourages the latter's violence. Quite simply, the Dude should never have engaged Walter in conversation.

Jean-Luc Nancy writes of myth in The Inoperative Community, describing how prior to the mythic scene humans existed as singularities, ${ }^{3}$ not linked by anything other than Mitsein, or being-with. Then a speaker-a poetstood up and began telling a story, and in this story the group of separate singularities began to recognize each other and cohere as a community. As the scene of myth, it is also the scene of a community's (re)presentation of itself: "Myth is of and from the origin, it relates back to a mythic foundation, and through this relation it founds itself (a consciousness, a people, a narrative)" (IC, 43-45). Nancy's description is concerned with how subjectivity is created generally, not just in terms of community. My concern here is less the communal subject than the individual subject and the national subject. The problem with this "consciousness" is that it necessitates separation from others who do not share a particular subject's values, leading to a process of assimilation in which difference is either incorporated or, in a more subtle way, incorporated by exclusion. 
The subject may then be described as wholly immanent, in that it is seemingly cut off from relation and absolute: everything is assimilated and brought within the structure. These are abstract notions of violence - that then may ground more concrete methods of violence, war (in the Persian Gulf) being the most obvious example. Myth, narrative, and consciousness are all linked to this violence.

The conversation between the "poet" Walter and his attentive addressee operates in such a fashion, forming a coherent narrative through the exclusion of noise and, therefore, creating a basis for action. As modern communication theory explains it, dialogue between two "opposing" parties - the pacifist and the Vietnam veteran, in this instance-is not oppositional, but the communication of two "variants of the Same" (Lingis, 86). Alphonso Lingis writes that "Discussion is not strife; it turns confrontation into interchange" (70-72). Their opposition is merely an illusion. Rather, the "rhythm" of their dialogue is mutually opposed to an "outsider" or "barbarian," or simply to difference. Rational communication occurs through an "extract[ion]" of background noise and a foregrounding of the message. In terms of myth, the poet must have "his" listeners, in order for myth to become myth. To listen, in this case, is to also engage in conversation, a conversation limited by the poet (Nancy, IC, 44). This is precisely the sort of assimilative operation seen between Walter and the Dude. By joining Walter in conversation, the Dude finds himself supporting the rational community. Donny, of course, throughout much of the film is the excluded barbarian to the Dude and Walter's conversation (Lingis, 157). Donny's interruptions are almost always noise. When Walter and the Dude are discussing Lenin, Donny assumes John Lennon, and inserts "and the Walrus" repeatedly and nonsensically into the conversation. And when Donny fails to pay attention to the conversation/narrative-" were you listening to the Dude's story?" - Walter never fails to notice (Coen, 11). The phrase "shut the fuck up, Donny" occurs five times in the screenplay, each time directly following Donny's attempt to enter the conversation $(38,75)$. The Dude never attempts to put a stop to this discursive violence.

The fight scene with the nihilists exemplifies this exclusion. While Walter and the Dude's individual identities as Vietnam vet and pacifist should make them oppositional entities, they fight off the nihilists together. Donny, simultaneously, heaves in the background, suggestively untouched by the nihilists but suffering from a heart attack. Engaging in a "conversation" with the nihilists amounts to a fatal exclusion. This scene could be read at a meta-level as emblematic of how the pacifist and 
the veteran through conversation oppose "nihilism," or the noise of the barbarian. When told that the Dude was threatened by nihilists, Walter responds, "Nihilists! Jesus . . . Say what you like about the tenets of National Socialism, Dude, at least it's an ethos" (Coen, 76). For a man who is so stridently Jewish, his horror of nihilism is very telling. It is not the well-defined, immanent subject that horrifies him. It is rather that which cannot be cognized due to its essentially non-metaphysical nature.

Narratives, as myths or stories, are monadic in nature: their assimilation of the world creates an inside and an outside within which a self like Walter is essentially imprisoned (Nancy, IC, 4$){ }^{4}$ The subject (Walter) can assimilate everything but death, since "Death irremediably exceeds the resources of a metaphysics of the subject" (14-15). Death, indeed, is the one thing that essence cannot be built upon. Death is that upon which "it is precisely impossible to make a work" (original emphasis). It is entirely possible, as in the Hegelian dialectic, for death to give rise to immanence (a supra-subject-patriotism, for instance), but this would be a work of death in which "death" is assimilated. An example of this sort of work of death occurs in the penultimate scene as Walter is "officiating" over the scattering of Donny's ashes:

.. Donny was a good bowler, and a good man. He was . . . he was
one of us. He was a man who loved the outdoors, and bowling, and
as a surfer explored the beaches of southern California from Redondo
to Calabassas. And he was an avid bowler. And a good friend. He
died-he died as so many of his generation, before his time. In your
wisdom you took him, Lord. As you took so many bright flowering
young men, at Khe San and Lan Doc and Hill 364. These young men
gave their lives. And Donny too. Donny who ... who loved
bowling . . . (original ellipses; Coen screenplay, 136)

Even as Donny's ashes are scattered, his senseless, noisy death is put to work by Walter as he interpolates Vietnam into the burial service. Derrida, in Cinders, considers "ashes" to be an apt word for the way that it points to both presence and absence - in this case, of Donny. As "ashes," as present and absent, Walter's commodification of Donny in a coffee can and his dumping of them signifies an extreme control over the very nature of identity, over différance (Lukacher, 1). However, it is a failed attempt, since the ashes do not so much scatter as cling to Walter and the Dude. This is also a particularly instructive speech, because its use of repetition gives the eulogy a sense of coherence and form, as if it were indeed crafted in the manner of myth. Of course, little of this information is true. Donny was not a veteran and his heart condition forbade surfing. All of which shows how the work of mourning and narrative elide difference. Donny was not "one of us" in the simple way that Walter indicates. We need 
only recall Walter's repeated exclusion of Donny from conversation. But the phrase nevertheless demonstrates the essence of myth - that is, the way it operates to create immanent subjectival identities. In this case, a previously marginalized individual augments the structure that essentially led to his death. Here Walter is the poet who brings together that which is dispersed and singular so that consciousness and a national subject can be realized in an essence that links death, war, God, and patriotism.

Subjectivity-national, communal, individual-is a work, in the sense that it operates, but also like a novel or a film, it constitutes a work or oeuvre. In this way, a subject and its representation are inextricable. A hierarchy results from such work in which the "work's" interior, or that recognized as "self," is privileged over the outside. Nancy describes this individual or community as a "common being" - with the emphasis on common, not being, to signify the work (via assimilation) and creation of a stable essence. Against this common being, he proposes being-in-common, pointing to the more verbal or active nature of identity and a way of being together upon which no exclusion can be based. His rethinking of community

... defines the impossibility, both ontological and gnosological, of absolute immanence ... and consequently the impossibility either of an individuality in the precise sense of the terms, or of a pure collective totality. $(I C, 6)$

Here the individual is no longer monadic, but is open and spaced out and into the other in a manner akin to the turning inside-out of a glove (within the monad there is not spacing, only the individual's pinpoint, atomic self).

This article tracks an experience in which sublation, this mythic work, is interrupted before the movement outside the subject to the other can return again and stabilize the subject created via myth. Opposed to such a subject would be one founded on an exposure to finitude and the impossibility of immanence, or non-relation. There is "knowledge" of this in the sense that it is not a subjectival knowledge, but a "consciousness" "of the interruption of self-consciousness" - a knowledge of singularity (19).

One scene both substantiates this reading of Walter and offers a sort of non-pacifist, or, perhaps, a genuinely (non-metaphysical) pacifist moment that interrupts the filmic narrative and is akin to this "spacing" 
I have just described. For this, we need to turn to a secondary character, the adolescent car-thief Larry Sellers, who enters the plot by way of an errant Social Studies test found in the Dude's car. As he begins interrogating Larry, Walter opens his briefcase and pulls out the test in a Ziploc bag, as if it were Exhibit $\mathrm{A}$ in a courtroom drama. In a commanding voice, Walter asks repeatedly, "Is this your homework, Larry?" (Coen, 93-94). Uncharacteristically dressed in a suit and tie, Walter is a parody of juridical reason. Larry remains silent, looking directly at Walter and the Dude with a blank face-a face that could reasonably convey an extreme moment of grief. Directly behind Larry, his father, Arthur Digby Sellers, lies in an iron lung, whose pump gives the only audible responses to these repetitive questions. Larry's silence unsettles both Walter and the viewer. In a simple comedy such as Lebowski pretends to be, this is a very non-comedic moment. Walter self-destructs, storms out of the house, and demolishes a car he assumes to have been purchased by Larry. When the vehicle's real owner enters the frame and begins to "kill" the Dude's car, Larry remains untouched and silent, watching from a window.

As a Vietnam veteran, Walter lives by a myth that is martial, and embodied by Larry's father, Arthur Digby Sellers, the author of a number of the Branded episodes, a series aired by NBC in 1965 and 1966. Though set in the 1880s, Branded was certain to strike a chord in Walter. The series centers around Jason McCord (Chuck Connors), the sole survivor of the Battle of Bitter Creek, accused of cowardice and dishonorably discharged (West, 23). Each episode opens with a vivid reminder of McCord's shame and impotence, as his saber is broken in half and his uniform stripped of decorations. Naturally, McCord is not guilty, and remains silent in order to protect his commanding officer, and hence the larger military structure. Thus Branded's narrative operates as an individualistic fantasy on one level-a heroic man cut off from all connections - while on another level it bolsters the military and, hence, the national narrative of conquest (which founds itself on "civilized" principles: honor, altruism, etc.). Such a contradictory logic duplicates the paradoxical logic inherent in a "nation of individuals." The series amounts to an endless proving ground for courage, both internal (silence about the truth) and external (actual violence). ${ }^{6}$ This proving needs to be understood as McCord's attempt to recover a semblance of immanence in the eyes of the world, despite his innocence, both for himself and for the narrative he protects and identifies with. This act of assimilation preserves a coherent and honorable narrative and is precisely the sort of act that Walter would respect. ${ }^{7}$ 
This is a crucial moment in my argument. In contrast to the assimilation of "death" with a patriotic narrative, in this scene with Larry we see an exposure to finitude and an unworking of the mythic narrative. I will discuss this question first on the level of sound, and then of image.

In light of the above reading of conversation, Larry's silence can be seen as a defiant, non-assimilative act: he will not join in a conversation that would amount to his assimilation and to the exclusion of the outside, the noise of the barbarian. A brief silence could be understood, but such a lengthy silence has no clear narrative motivation whatsoever. As verbally violated "outsider," it is fitting that Donny is told to remain in the car as Walter and the Dude head into their interview with Larry. Larry's silence can then be read as an answer to Donny's violent exclusion. If Larry immerses himself in the assimilative give-and-take of rational discourse, Donny will be easily forgotten. Larry's silence, however, forces Walter and the Dude to return to Donny-i.e., the noise they would prefer to ignore.

Indeed, in a film whose plot is motivated in large part by witty, fastpaced conversation, Larry's prolonged silence amounts to a moment of excess, as theorized in Kristin Thompson's "The Concept of Cinematic Excess" (130-131). Film is constituted by sound and images. When these components are not fully assimilated to the narrative, excess is foregrounded. This could be the chance movement of a fly across a still or something as anachronistic as a wrist watch in a Biblical epic. In this case, the absence of a flurry of words is excessive insofar as this moment does not fit with the characteristic narrative style of the film. ${ }^{8}$ This is dead air. If film, like all narrative, is defined by its attempt to create a homogeneous field, excess in a film indicates that which cannot be assimilated to a "unifying effect." Stephen Heath argues, "Just as narrative never exhausts the image, homogeneity is always an effect of the film and not the filmic system, which is precisely the production of that homogeneity. Homogeneity is haunted by the material practice it represses" (original's emphasis; Thompson, 130). In a homogeneous field defined by obsessive repartee, silence must appear as the work that takes place prior to all speech: the silence, before speech, is drawn out in this scene, revealing the "material practice" - the work or writing/filming, that allows speech/narrative to appear so fully present throughout the rest of the film. Narrative meaning is immediately undermined at such a moment, allowing the viewer to see it in its arbitrariness and as a mediated un-natural presentation $(132,140)$. 
This breakdown in narrative-and hence in meaning - coincides with a more general hermeneutic stall. Keeping in mind that Lebowski is on one level a revision of The Big Sleep, Walter and the Dude in this scene are also simultaneously detectives. Peter Brooks has argued that detective fiction in many ways is exemplary of the nature of narrative. If plot is defined through the interplay of fabula (actual events) and sjuzet (the presented events), then the detective's job (as with the viewer/reader) is to reconstruct the fabula of a crime (13). In this particular case, we encounter an opaque moment in the narrative in which the fabula resists assimilation by its reader detectives. It is true that hermeneutic gaps remain even at the end of the film, but these are easily covered over by a return to the proairetic. Here, this opacity cannot be fully recovered, leaving not only the "detectives" but also the viewer in the dark as to the actual events: the hermeneutic adventure stalls. More importantly, the very nature of narrative (as interplay between fabula and sjuzet) is highlighted at this moment, further de-naturing that which is so commonly accepted as natural. Walter, erstwhile detective, leaves the house muttering about "language problems" and "stonewalling."

Following from this sonic excess, we also encounter visual excess. In a film that contains a parody of a Busby Berkeley dance sequence, it is difficult not to reference Laura Mulvey on the issue of visual pleasure. Mulvey writes:

The magic of Hollywood style at its best (and of all the cinema which fell within its sphere of influence) arose, not exclusively, but in one important aspect, from its skilled and satisfying manipulation of visual pleasure. Unchallenged, mainstream film coded the erotic into the language of the dominant patriarchal order. In the highly developed Hollywood cinema it was only through these codes that the alienated subject, torn in his imaginary memory by a sense of loss, by the terror of a potential lack in fantasy, came near to finding a glimpse of satisfaction: through its formal beauty and its play on his own formative obsessions. (1446)

Mulvey's interest is in denying visual pleasure that arises either from the power that the objectivism of voyeurism conveys or from ego identification with Hollywood's stars (1448). In classic Busby Berkeley's dance numbers, erotic contemplation of the female form was vital. But this pause could not last too long or endanger the narrative's coherence, and, by extension, the phallogocentric order. The Berkeley routine in Lebowski does not pause at all. Instead of a traditional erotic figure wearing suggestive clothing, we see a figure costumed as a Valkyrie-armor and all. "Gilda" has been transformed into Maude, the feminist. Ultimately, the dream/dance sequence blurs into castration anxiety. 
However, we do see such an erotic suspension during Larry's interrogation - though, once again, with a difference. The camera focuses on the impassive face of Larry in a way that, if he were a woman, would seem quite "natural" in view of past Hollywood practices. The fact that Larry is male indicates that this gaze is not only erotic, but homoerotic. For Walter and the Dude, this can only highlight the implicit homoeroticism in all buddy movies (Mulvey, 1449). Insofar as this scene and Hollywood film in general puts the viewer in the eyes of the main male characters, we are also confronted with our objectifying voyeurism (and homoeroticism, in some instances). Realism, after all, demands that the gaze of the camera and the audience be marginalized, not ostentatiously out in the open (1453). The scene reproduces the situation between viewer and viewed: the viewer being the active interrogator (Walter, an "Eye-rackie," if you will) and the viewed, the mute, passive object (Larry). During this lengthy narrative stall, it becomes very difficult for the viewer to not become aware of his or her own complicity in voyeurism. Interestingly, when Walter leaves the house to wreak havoc on the wrong car, Larry moves to the window, looking out at Walter and reversing the direction of the gaze: Larry now seems to be in a position of power. ${ }^{10}$

The scene is never integrated into the plot, leaving the viewer as selfconscious as Walter. By destroying the corvette, Walter attempts to mend the fabric that is his subjectivity and the film's narrative. His actions shake the film back into the non-reflexive proairetic violence that motivates plot. As he destroys the car, he screams, "this is what happens when you fuck a stranger in the ass," underlining once more how the question of a "natural" or coherent narrative connects so closely with immanence and the exclusion of finitude.

While it is true that the elder Sellers is not dead, his presence in an iron lung certainly suggests that death is near. Sellers cannot exist on his own, but relies on that which is outside to sustain his life. If individualism is defined by absolute immanence (Derrida's self-presence), here is a moment in which the Western myth of the individual founders. Sellers exists only in relation to the outside. He is, as Derrida might say, both present and absent. As previously mentioned, death is the one thing that cannot be assimilated by the subject. It, alone, exposes us to the spacing of identity. Walter's identification with Sellers can only "magnify" this exposure (as if exposure could be magnified). If his hero can die, then Walter's own mortality must also come under this shadow. Sellers's impending death confronts Walter with the finitude of his own obsessions: 
patriotism, Vietnam, and religion. Sound and image emphasize this exposure to finitude and subjectival interruption along with a tightly controlled mise-en-scène. Larry's placement and passivity in front of his father makes it impossible not to see Sellers lying in the iron lung.

Walter indicates this interruption in a small, but telling manner. Before Larry has even entered the frame, Walter yells across the room to the supine Sellers, "I just want to say, sir, that we're both enormous-on a personal level, Branded, especially the early episodes, has been a source of, uh, inspir[ation]" (Coen, 93). In the middle of the speech, Walter becomes emotional for an instant before returning to his business face for the interview with Larry. This is the only moment in which Walter's subjectivity is interrupted. In all his previous interaction with the Dude, the Dude cannot shake Walter's rational mask. ${ }^{11}$ However, it is only shaken for a moment. And perhaps this is where Walter's last name becomes telling: Sobchak -"sobcheck"? ${ }^{12}$

As he leaves the house, Walter screams "You're KILLING your FATHER, Larry!" with a long pause ensuing as he waits for a response (95). This makes little narrative sense, since Sellers is completely immobile. We can only suppose that this "KILLING" has much more to do with how the stall in conversational reciprocity threatens the myth that Sellers represents. We need only note the breakdown of the filmic narrative-coextensive with Walter-to see the spacing that is beingin-common. For example, if conversation operates as myth to create a unitary consciousness, Larry's radical disinterest in Walter (due to exposure to his father's illness) leaves the substance of this myth hanging. The breakdown of the narrative means that the narrative borders have momentarily dissolved and the narrative "self" (and those selves that it limits) has spaced out and into the other. However, this interruption ripples throughout the film. Since the film opens and closes with a famous western actor (The Stranger) it can be seen as striving toward a traditional cowboy western narrative only to fail because the originwriter Sellers-lies gasping in an iron lung, incapable of speaking and making his narrative cohere. Once again: the death of the other overwhelms the capabilities of the rational subject as well as the subject's myths. The Big Lebowski is postmodern in the sense that it shows us not only the death of the poet, a writer of Westerns and, in a way, of Lebowski, but also the unworking that results. This spacing allows for all the inversions and impurities of the Lebowski "narrative" alluded to in the introduction. 
Where then should we locate the origin of Walter's inability to remain in this non-subjectival space of being-in-common? The poet may be dying, but the myth lingers. How and to what extent this myth remains operative needs to be considered. The western myth of monadic individualism crucially contains Sellers, the "original" mythmaker. It also includes The Stranger, the Dude, Walter, and Branded's McCord who can all be considered Sellers's work to some extent. Such a list, however, leaves out a more famous Texan, President George Bush, whose words"This is a call for collective action [read totalized supra-subject] ... this aggression will not stand" - assist in framing the film. A phrase, as we have seen, that is also reproduced by the Dude. Following September 11, the younger George Bush was also heard saying, "Terrorism against our nation will not stand." The manner in which the phrase, slightly different, floats through time, film, and the real world should give us pause. Bush Sr.'s statement operates as a center that changes location and context while remaining essentially unchanged in substance. While the Branded myth defines all of these characters, the Bushes are important because they magnify, extend, and discursively control those who hear and enter into conversation with them. The repetition of this phrase and its discursive control needs to be understood in light of the early conversation between the Dude and Walter, in which the Dude's conversational participation leads him to repeat Walter's argument word for word. The same mode of control is working at the larger national level, with Bush displacing Walter.

If nothing else, this indicates the discursive power of the technopolitical apparatus that is so inextricably linked to myth. Walter, trapped by Vietnam and Persian Gulf rhetoric, may be thought of as actualizing Bush's imperative. He owes his inability to enter into being-in-common to the discursive-imperative power of the techno-political establishment that can continue to operate long after the "origin" (Sellers) has fallen ill. The myth continues as long as its story has a speaker and a listener, and in the absence of the death of the other. Walter becomes, like the Dude, subject to an imperative that exerts tremendous force to ensure that he does enter the conversation in the proper manner, or risk being shunted aside as yet one more "barbarian."

As Walter repeatedly tries to make sense of events through the lens of the Vietnam War, it becomes clear that he is an extreme example of one who has actualized his life around an experience that he cannot leave behind. This military experience has become such a part of his subjectivity that he is trapped, unable to leave the paths that he created 
(Lingis, 161). Walter "Sobchak" must keep his tears/sobs in check because to let them go would be radically to question his identity. This identity, a creation of the most extreme rationalist enterprise-war-exists at an equivalently extreme level of instrumentality. War, in view of its ostentatious violence, requires the most extreme form of depersonalization. Any subjectivity created through a martial experience must be equally rigid. But for Walter, what is frustrating is the fact that the ordered world he has created for himself-a world that does not threaten him because he (and Bush) creates it and limits it-is endangered. Endangered as it is, it also threatens the series of decisions that brought him to his particular identity and, hence, his identity generally.

While all of the above is true, we have not yet touched on the most primordial reason. Walter, McCord and Bush share an exposure to death that was never properly mourned. Let's consider Walter first. Twice we hear Walter say something to the effect of "Lady, I got buddies who died face down in the muck so you and I could enjoy this family restaurant!" (Coen 70, 38). In Walter's characteristic way, an argument over his strident cursing rapidly becomes an issue of patriotic freedom. This image of death in the "muck" of Vietnam speaks to a sense of dishonor and of death that is not properly observed. Derrida writes that "Nothing could be worse, for the work of mourning, than confusion or doubt: one has to know who is buried where-and it is necessary (to know - to make certain) that, in what remains of him, he remain there. Let him stay there and move no more!" (original emphasis; Spectres, 9). Mourning is first of all an attempt to "ontologize remains, to make them present, in the first place by identifying the bodily remains and by localizing the dead." Avital Ronell writes of how war generally rejuvenates the nation as it "stages the infinity of a finitude that encounters its end" (282). Yet this was ("possibly") not true for Vietnam, where our soldiers became "abject" and war became "shameful."

Walter's obsessive assimilation makes sense against such a backdrop. In this scenario, not only are there dead soldiers, missing prisoners of war, but also an entire war that never properly found subjective closure. That (lost) war remains for him a wound that requires perpetual care. The strangely poetic eulogy given at Donny's funeral is the summit of such ontologizing. Donny's death allows Walter to relive his experience in Vietnam, not just by interpolating Vietnam into the eulogy, but even during the prior conflict with the nihilists, by allowing the full experience of combat, death, and funeral rites to be performed. This is crucial because it allows him to simulate the Vietnam war and right it. Since he retains the body and can officiate at the funeral, he is able to put Donny, the 
horror of his death - and, most important, Vietnam - to rest in the proper way. How else are we to understand the interpolation of Vietnam into the eulogy?

While a prolonged reading of Branded is perhaps necessary here, the basic plot of the series appears to operate similarly. Branded's plot could be read as the fallout of a lost battle in which a nation's and a man's pride were wounded. McCord becomes a Walter-like character from this perspective, obsessed with ontologizing the wound in his and the nation's psyche. In a more psychoanalytic vein, Ronell writes of Bush, Sr.:

\begin{abstract}
This time, when history repeated itself, it was not a joke but the production of a haunted man to whose systems of repetition compulsion we were all assigned. There was the matter of resurrecting Hitler in the Middle East, and a felt need to control airspace. The Patriot missile system perforated two phantasmic oppressions: the Germans had never lost air control during World War II, and George Herbert Walker Bush's was not the only one of the three planes on mission to go down [that?] day [sic]. When the Avenger plunged into the ocean, young Bush, the youngest fighter pilot in the U.S. Navy, lost two close friends. Puking from fear and endless seawater, the youngest pilot started attending a funeral whose site he would never be able to pinpoint. (270-271)
\end{abstract}

Bush, haunted, spends the rest of his life trying to seal the rift that this plane crash created. The Persian Gulf War becomes a way of finding closure, of winning back the skies for the good moral program represented by the U.S., and of putting an end to the weeping, the funeral, that began on the day he crashed (272). Like Bush, Walter and McCord are "delivered to a history of denial and compulsive repetition" intent on "restoring the national phallus to its proper place" $(280,282)$.

The horror, in short, is an exposure to finitude in which the "subject" confronts that which cannot be assimilated - the death of the other (the dead in Vietnam, World War II, or at Bitter Creek)-and, hence, "recognizes" the impossibility of immanence, thereby being thrown into being-in-common. All mourning, all assimilation, is an attempt to erase the "memory" of this exposure. Walter's encounter with the poet (Sellers) who created the myth that formed his identity and aided his acceptance of the deaths and killing in Vietnam, before and after the war, undermines him. This inextricable linkage of man and myth indicates that, at least in this instance, the death of the other is not enough to expose one to beingin-common. It takes the death of an other who embodies the myth that the subject has identified with, in order for exposure to occur. In light of this, it is not surprising that Donny does not interrupt Walter's assimilation. Instead, he is put to work augmenting subjectivity. It is intriguing because Donny had no "use" prior to his death. The death of this other, this excluded barbarian who cannot enter into the myth or 
the conversation, can be used, however, in the work of mourning.

It is such a traumatic exposure to finitude that prompts mourning that is "not one kind of work among others. It is work itself, work in general" (Derrida, Spectres, 97). Mourning needs to be understood as linked to "trauma, to mourning to the idealizing iterability of exappropriation, thus to the spectral spiritualization that is at work in any tekhne." A specter can be thought of as equivalent with that spacing of being-incommon in which the other interrupts the subject profoundly. The specter is linked by its very nature to trauma, since it threatens identity at a fundamental level. To encounter the specter, différance or being-in-common in the death of the other is truly traumatic and must be spiritualized, or ontologized, through art (tekhne) - which is to say, through myth.

I am juxtaposing Derrida and Nancy here because mourning is the essence of all work, even the work of what Nancy terms "operative" communities. For both, ethics is a matter of being open to alterity, but how to evade what the one terms immanence and the other presence? How to be just to the specter? In light of the amount of mourning in The Big Lebowski, the question might be better posed: How to properly mourn when "proper" can have nothing to do with the subject? Derrida writes of "A mourning in fact and by right interminable, without possible normality, without reliable limit, in its reality or in its concept, between introjection and incorporation" (Specters, 97). Such a mourning - to answer the question broached in the introduction - would be heroic. Only Larry, mute before his father's body, represents such a mourning without reserve. More generally, the specter demanding justice is the experience of war, the dead glossed over by the triumphant Western narrative "originating" in Branded and its descendants (Walter, The Stranger). Only the death of the other, in particular the death of one who embodies the mythic narrative, allows for an encounter with the specter.

Walter was right about one thing. Donny did love bowling. When he returns from rolling a strike and says to his opponents, "you guys are dead in the water," this is not a threat. Donny's joy in the game and his noise throughout the film indicates as much. The threat comes shortly enough when Walter pulls a gun over a question of a foul. I'd like to consider what it might entail to be "dead in the water." Water has been a leitmotif in the Coens' films at least since Barton Fink, finding its fullest exposure in $O$, Brother. In The Big Lebowski, three key moments are signaled by water: during the crucial scene with Larry, a painting of the ocean is placed directly behind Walter; the opening shot of the tumbleweedidentified with the Dude-founders in the ocean; and, the burial scene occurs on a cliff overlooking the ocean. 
The phrase immediately evokes paralysis - the paralysis of a mythmaker, both present and absent, in an iron lung perhaps. It is just as clearly linked to death at sea, in particular the uncertainty of wives waiting for long overdue sailors who may be "dead in the water" and confronting "death in the water." For Bush, Sr. this signals the disappearance of his two crewmen when he bailed out over the ocean. For Walter, this signals those friends who died overseas in the "muck" of Vietnam without eulogy and without burial. For McCord, this signals the death and dishonor of Bitter Creek. For those on the "mainland," it becomes a matter of perpetual uncertainty, of an "interminable" mourning that finds no end. Proper mourning - the mourning linked with immanent subjects - requires presence and identification, whereas dead/death in the water points to the impossibility of such ontologizing. The dead at sea remain unburied and obscenely on view, both present and absent: we are interrupted by such a "presence" and faced with the impossibility of our immanence, with being-in-common. If we take seriously this use of "dead in the water," its repetition marks our responsibility to the specter, the dead, who claim our attention because they cannot be entombed and put to work by the subject.

Michigan State University

\section{Works Cited}

The Big Lebowski. Polygram Filmed Entertainment. 1998.

Brooks, Peter. Reading for the Plot: Design and Intention in Narrative. New York: Vintage, 1985.

Bush, George W. "Terrorism Against Our Nation Will Not Stand." International Information Programs. 11 Sept. 2001. 15 Sept. 2004. <http://usinfo.state.gov/is/ international_security/terrorism/sept_11/sept_11_archive/ Terrorism_Against_Our_Nation_Will_Not_Stand_Bush_Vows.html .

Churchill, Ward. Pacifism as Pathology: Reflections on the Role of Armed Struggle in North America. Winnipeg, CA: Arbeiter Ring Publishing, 1998.

Coen, Joel and Ethan. The Big Lebowski. London: Faber and Faber, 1998.

Derrida, Jacques. Spectres of Marx.: The State of the Debt, the Work of Mourning, and the New International. Trans. Peggy Kamuf. New York: Routledge, 1994.

Haraway, Donna. Simians, Cyborgs, and Women: The Reinvention of Nature. New York: Routledge, 1991.

Heidegger, Martin. Being and Time. Trans. Joan Stambaugh. Albany: State University of New York Press, 1996.

Lentz, Harris M. Television Westerns Episode Guide: All United States Series, 1949-1996. Jefferson, NC: McFarland and Company, 1997.

Lingis, Alphonso. The Community of Those Who Have Nothing in Common. Bloomington: Indiana University Press, 1994.

Lukacher, Ned. "Introduction: Mourning Becomes Telepathy." Cinders. Lincoln: University of Nebraska Press, 1991. 1-18. 
Lyotard, Jean-Francois. "A L'insu (Unbeknownst)" Community at Loose Ends. Ed. Miami Theory Collective. Minnesota: University of Minnesota Press, 1991. 42-48.

Mulvey, Laura. "Visual Pleasure and Narrative Cinema." The Critical Tradition: Classic Texts and Contemporary Trends. Ed. David Richter. Boston: Bedford Books, 1998. 1444-1453.

Nancy, Jean-Luc. The Inoperative Community. Trans. Peter Connor. Minnesota: University of Minnesota Press, 1991.

-. "Of Being-in-Common." The Community at Loose Ends. Ed. Miami Theory Collective. Minnesota: University of Minnesota Press, 1991.

Ronell, Avital. Finitude's Score: Essays for the End of the Millennium. Lincoln: University of Nebraska Press, 1994.

Thompson, Kristin. "The Concept of Cinematic Excess." Narrative, Apparatus, Ideology: A Film Theory Reader. Ed. Philip Rosen. New York: Columbia University Press, 1986. 130-142.

West, Richard. Television Westerns: Major and Minor Series, 1946-1978. Jefferson, NC: McFarland and Company, 1987.

\section{Notes}

1. There are small differences between the screenplay and the actual film. In the published screenplay Bush says, "This aggression will not stand ... this will not stand" (Coen, 5).

2. Ward Churchill writes, "Pacifism, the ideology of nonviolent political action, has become axiomatic and all but universal among the more progressive elements of contemporary mainstream North America. With a jargon ranging from a peculiar mishmash of borrowed or fabricated pseudospiritualism to 'Gramscian' notions of prefigurative socialization, pacifism appears as the common denominator linking otherwise disparate 'white dissident' groupings. Always, it promises that the harsh realities of state power can be transcended via good feelings and purity of purpose rather than by self-defense and resort to combat" (30).

3. Nancy's term for an "individual" that possesses identity while not being monadic in nature.

4. In "Of Being-in-Common" Nancy appears to revise his emphasis on relation in The Inoperative Community by arguing that "'relation' is too exterior for something which does not allow separation of interiors from exteriors" (4).

5. Sellers is not listed as a writer in any of the sources I have consulted.

6. Many of the episode titles explicitly thematize courage, cowardice, and heroism (Lentz, "Branded").

7. This is a good moment to note that Walter's privileging of the Western myth once again indicates his similarity to the Dude who, recall, was introduced and praised by Sam Elliott, a famous cowboy actor, playing The Stranger.

8. Of course, once one component is seen as excessive, it is difficult for other areas of excess not to arise. During the interrogation by Walter, the Dude's rapid head- bobbing becomes excessive.

9. The case breaks only after the Dude has had sex with Maude. Hermeneutic progress is intimately connected to sexual prowess, though it should be said that Maude is clearly the predator even in this scene.

10. As if the relation between viewer and viewed could be problematized any more, the immediately previous scene shows Walter, the Dude, and Donny at a theatre. At the very least, this assists in foregrounding this relation in our minds. 
11. Walter's misdirected attack on the car also points to the degree to which Walter has been shaken by his exposure to finitude.

12. There is a difference between affect and an exposure to finitude; however, in the scene in question it is clear that these two are related. The issue of manhood and tears comes up directly in a conversation between the Dude and the big Lebowski, who is not so much in opposition to Walter as a mirror image of the latter's own obsessive assimilation ("Strong men also cry") (33). Walter also describes the nihilists as crybabies. Tears are linked to non-meaning, an exposure to finitude where meaning is undermined. 